\title{
Factors Influencing the Financial Performances of Saving and Credit Cooperative Societies in Case of Derash and Alle Woreda in SNNPRG, Ethiopia
}

\author{
Negalign Nigatu Oynaka \\ MSC in Accounting and Finance, Lecturer in Wolaita Sodo University
}

\begin{abstract}
The study aims to identify factors influencing financial performance of savings and credit cooperative societies of the study area. To achieve the "general and specific objectives" the study was look factors influencing the financial performance of SACCOS. This study also used descriptive research design and quantitative research approach were used and the primary sources of data were collected from 220 staff members of SACCOS from Derash and Alle Woreda Southern Region. The sampling techniques were stratified sampling method. For data analysis, descriptive statistics including mean, std. deviation, frequency and percentages were used. The results of the study indicated loan repayment, interest rates, membership enrolment, and duration of loan processing, management of loan defaulters were identified as factors influencing the financial performance of savings and credit cooperative societies. In general to increasing the financial performance it suggests that SACCOs in the region should strengthen its applicant screening criteria and due diligence assessment to select potential risk taking applicants and adopt appropriate pre and post credit risk assessments. Besides, the SACCOs needs to make sure that borrowed funds are being used for the intended purpose through enhanced credit monitoring
\end{abstract}

Keywords: SACCOS, Financial performance, Loan repayment, loan defaulters

DOI: $10.7176 / \mathrm{EJBM} / 12-16-04$

Publication date:June 30th 2020

\section{Background of the Study}

Savings and Credit Cooperative Societies (SACCOs) are voluntary associations of people who have come together with the common goal of encouraging savings and granting credit to members in order to improve their livelihoods. The main purpose of Savings and Credit Cooperative (SACCOS) is to promote the social and economic benefit of their members who could be both net savers and net borrowers. Members pay an entrance fee and invest funds to purchase at least one share in the society. In addition, members are expected to deposit their savings in the credit society and these funds are only lent out to members as per their By-law stipulation and not to the general public as is the case of commercial banks. Generally, in establishing the credit society, members have a common bond, such as that of occupation or social association (Amina, 2016). Worldwide the first cooperative society was formed in 1844 in a village known as Rochdale in England. It was formed by a group of people known as the Rochdale pioneers when Britain was undergoing the industrial revolution (KNFC Website). In Germany, the first SACCOS were launched in 1846 when there were an Agricultural crisis and drought in Europe (Birchall, 2004). The theory explains that SACCOs are under intense pressure to operate like other financial institutions and particularly the banks. The competition aspect is the fact that all financial institutions are focusing on the same people called investors. Thus, in order to deliver returns or benefits similar to the ones offered by other financial institutions particularly the banks, the SACCOS had to change a mode of doing businesses and thus increasing risks substantially.

In Africa, the first SACCOS were introduced by Father John Nenulty in Ghana in 1959. The aim was to assist villagers to improve their economic conditions, (Jesse, 2016) as quoted from (Mwikamba and Ngombe, 2004). English speaking nations were the first to adopt SACCOS. The first entrants into SACCO's community were Ghana, Uganda, Nigeria, Tanzania, and Kenya. Mumanyi (2014) asserts that the achievement of the cooperative movement in Ghana has been widely simulated throughout the African continent. Cooperative efforts have occurred throughout history. Since the early days, man cooperated with others to help kill large animals for survival. This objective would not have been reached if men would have acted individually (Cobia, 1989). Since then, regulatory reforms have been instituted to help streamline the SACCOS operations for maximum returns to members. Establishment of saving and credit cooperative societies in Ethiopia started in the mid-1960s. From 1964-1973, there were 28 saving and credit cooperative societies and these societies formed their own national apex body known as Ethiopian Thrift and Cooperative Societies Limited (Muluneh,2012). SACCOs have been growing fast since 1979, however; the rate of growth is slower than other types of cooperatives in Ethiopia. In 1991 the number of SACCOs in Ethiopia was 3,491 (Dessalew, 2014). During the Derg regime (1974-1991), different types of cooperative societies (Agricultural Cooperatives, Housing Cooperatives, Saving and Credit cooperatives and Mining Cooperatives) were organized, promoted, regulated and inspected by different ministries and institutions ( Muluneh,2012). During the Derg period, Proclamation No. 138/70 was issued which provided 
the National Bank of Ethiopia to promote and organize SACCOs. These cooperatives were not demand-driven and member managed. There were frauds, embezzlement and mismanagement. However, the saving and credit cooperatives (SACCOs), mainly in urban areas, which were insulated from government interference, continued to thrive. After the fall of the Derg regime in 1991, adoption of Economic Reform Program helped the organization, promotion and development of cooperative societies within the framework of free market economy. This opportunity opened to turn cooperative societies into real people's organizations and the number of saving and credit cooperative societies mushrooming up both in urban and rural areas have increased tremendously. Generally, the poor are considered credit risk to the conventional banks and hence excluded from the credit market ( Muluneh,2012).

\section{Statement of the Problem}

Ethiopia has low geographic and demographic bank branches. Micro-finance institutions meet only about $20 \%$ of the demand for financial services for the excluded. In 2010 , only about $0.1 \%$ of the Ethiopian population has access to insurance services. In the case of SACCOS, their capital base is very small to support the lending programs and ensure sustainability (Muluneh, 2012). Various studies have been conducted on SACCOS by a number of researchers; Management of Savings and Credit Cooperatives from the Perspective of Outreach and Sustainability Kifle (2011) and he concluded that those grassroots and member-owned financial institutions called the saving and credit cooperatives were able to mobilize huge financial resources and to provide credit and savings services to a large mass base at a standard compared to that of formal financial institutions. According to him SACCOS are viable financial institutions whose development must be strongly supported. According to him lack of awareness and poor saving culture, weak organizational arrangement and governance problems, policy and regulatory environment, weak institutional capacity, low capital base, lack of differentiated products, inappropriate loan security requirements are identified as the factors that affect the growth/outreach of SACCOS. In addition Kifle (2012) also conducted on The Impact of Savings and Credit Cooperatives in Ofla Wereda Tigray Region of Ethiopia and come out with there is Positive significant correlation have been observed between seniority, saving, size of loan, number of times loan availed and post income of the respondents. Similarly for profit, there is significant and positive correlation between seniority, the size of loan and number of times loan availed and profit from economic activities while the variable saving had significant negative correlation with the profit. Although SACCOs has been present in Kenya since 1970s, this sector has not been able to impact positively on the lives of people. In light of this, the existence and flourishing of SACCOS in Kenya have not been able to perform well as compared to the other mainstream financial institutions like commercial banks. SACCOS are formed to serve the special needs of its members, but this has not been possible because of the various challenges that impacts on their financial performance. One of the justifications of the advancement of a financial institution is one that is profitable and has financial sustainability. Mvula (2013) presented a report on common issues affecting performance of SACCOs in Malawi and pointed out that the issues affecting performance of SACCOs are inadequate capital, poor asset quality, poor governance, poor profitability, poor liquidity and noncompliance. On the other hand Mudibo, (2005) discussed some of the factors affecting performance of SACCOs as weak regulation, limited product and services, low marketing and poor image. However the effect of interest rate charged and the rate of loan repayment on Sacco performance is yet to be established. Further the management of loan defaulters with the local SACCOs is very poor. This is because SACCOs finance people of low income and unreliable employments hence the chances of default are very high. Fredrick Wanyama (2008) pointed out that SACCOs are formed from mostly the producers of cash crops and basic products hence there are market risk in their marketing but in this research membership enrolment and the duration of loan processing that have affected the financial performance of SACCOs have not been identified. According to Karagu and Okibo(2014), the deterioration of financial performance in SACCOS is also due to fund misappropriation, member withdrawals and the diversity of products offered to be the key factors. However, the growth and sustainability of SACCOS depend on good repayment loan policy, good management on loan defaulters and membership enrollment.

The seeds of present study are sowed in attempting to find major influencing factors or bottlenecks that affect the financial performances of SACCOS in Ethiopia. It is believed that the factors influencing the financial performances of SACCOS would vary depending on inadequate capital, poor asset quality, poor governance, poor profitability, poor liquidity and noncompliance. To facilitate the present study, the causes for financial performances of SACCOS are: loan repayment, interest rate charged, membership enrollment, duration of loan processing and management of loan defaulters are the major independent variables which affect the dependent variable.

There was no study conducted so far in southern region on this issue, however there was an attempt made on other regional and national levels.

Therefore, this study may prove critical in bridging the knowledge gap by identifying the factors that influence the financial performances of SACCOS in Derash and Alle Woreda; Southern Ethiopia. Finally, this study would attempts to provide answers for the following basic research questions; 
1. How do loan repayment influence financial performance of SACCO in Derash and Alle Woreda?

2. How does interest rate charged influence financial performance of SACCO Derash and Alle Woreda?

3. How does membership enrollment influence financial performance of Capital SACCO Derash and Alle Woreda?

4. How do duration of loan processing influence financial performance of Capital SACCO Derash and Alle Woreda?

5. How does management of loan defaulters influence financial performance of Derash and Alle Woreda?

\subsection{Research Objective}

The general objective of this study is to identify factors influencing the financial performance of saving and credit cooperative societies (SACCOS) in case of Derash and Alle Woreda southern region Ethiopia.

Based on the above stated general objective the following specific objectives are drawn:

> To determine how loan repayment influence financial performance of SACCO in Derash and Alle Woreda?

$>$ To establish how interest rate charged influence financial performance of SACCO Derash and Alle Woreda?

- To examine how membership enrollment influence financial performance of Capital SACCO Derash and Alle Woreda?

- To evaluate how duration of loan processing influence financial performance of Capital SACCO Derash and Alle Woreda?

> To assess how management of loan defaulters influence financial performance of Derash and Alle Woreda?

\section{LITERATURE REVIEW}

\subsection{Theoretical Review}

\subsubsection{The concept of financial performance of savings and credit cooperative societies}

The financial services sector is very significant sector in today's modern economies. SACCOs like other financial institutions play a great role in the economy by mobilizing savings and allocating credit for investment thereby helping to improve people's living standards. Cooperatives can provide financial services to their members through existing products and the members also have the opportunity of saving with the cooperative but this is possible if the cooperatives are financially sustainable.

The financial performance of a SACCO is measured through the ability of the institution to meet the financial demands of its members taking consideration of economic status of the members. SACCO is expected to give better and cheaper services to its members as compared to the main stream banks because SACCO understands the needs of the members because they are the owners of the SACCO (Wanyama 2008).

Through mobilization of funds the SACCOs in Kenya offer loan services, deposits, front office services. The most common product offered through the SACCO community is the credit and loan services. Many of the institutions have no institutional capacity or capital base to offer other services. Depending on what kind of loan a member is applying for, the size of the loan and period of the payment of the loan, the loan interest of the most savings and credit cooperative societies varies from $10 \%$ to $18 \%$. Once a member applies for a loan, approval is ideally supposed to take between 14 to 30 days but this is not always the case because of cash liquidity problems that makes them take longer. The loans are screened and approved by credit committee. A SACCO is said to be performing well financially if it is able to process member's loans timely and at appropriate rates, Microfinance House Ltd, (2006). SACCO s experience a wide range of problems partly owing to the fact that they target low income earners and have to establish a balance between serving them adequately and also meeting their operation cost.

Majority of the people in Kenya measure the financial performance of SACCOs by the rate of dividends that they pay to its members which is not true. Some SACCOs pay dividends even if institution did not make any profit which is against the law. All SACCOs should pay dividends out of profits. A SACCO is said to be performing well financially if it has the capacity to expand their products range, has sufficient funds to provide services and the client base is growing (Microfinance house ltd, 2006)

\subsubsection{Loan repayment policy and financial performance of SACCOs.}

The role of credit is to bridge the gap between enterprise owners' financial assets and the required financial assets of the enterprises. Due to persistence of this imbalance enterprises are forced to demand credit. With the growth of the number of SACCOs in Kenya, access to credit is not difficult but repayment is never $100 \%$, Besley and Coate( 2005). Lenders of funds in the formal financial sector use the deposits of their clients while lenders operating in the informal financial sector use mainly their own funds to advance money to borrowers.

Most lending institutions do not have experienced personal capable of developing appraisal procedures for different category of borrowers. The repayment of loans by the poor and SMEs is recognized as one of the most troublesome problem facing rural SACCOs in Africa. Collateral, access to basic information and appropriate loan mechanism to enforce loan repayment are important tools. 


\subsubsection{Interest rate charged and financial performance of SACCOs}

Interest rate is the amount of interest paid per unit of time expressed as a percentage of the amount borrowed. The cost of borrowing money measured in shillings per year per amount borrowed is the interest rate. Interest rates differ mainly in terms of maturity. When maturity and liquidity together with other factors are considered, many different financial instruments and so many different interest rates will emerge, Anyanwu (1997). Interest rates can either be nominal or real. Nominal interest rate can be measured on monetary terms not in terms of goods. The nominal interest rate measures the yield in money per year per the amount invested while the real interest rate is calculated as the nominal interest rate minus the rate of inflations (Pandey 1999). A lot has been reviewed in terms of lending activities of various deposit money banks. Some opinions deliberated on the factors responsible for banks willingness to extend much credit to some sector of the economy, while some discussed effect of such extension of credit on productivity and output. Felicia (2011) used regression analysis to investigate the determinants of commercial banks' lending behavior in Nigeria. The study discovered that interest rates charged has the greatest impact on the lending behavior. Individuals are motivated by low interest rate charged to take more loans. Interest rate risk is the risk to earnings or capital arising from movement of interest rates. It arises from differences between the timing of rate and the timing of cash flows from changing rate relationship among yield curves that affect banks activities, from changing rate relationship across the spectrum of maturities and from interest rate related options embedded in bank products. The movement of interest rates affects the financial institutions reported earnings and book capital by changing net interest income, market value of trading accounts and other interest sensitive income and expenses. Changes in interest rate also affect banks underlying economic value. The value of banks assets, liabilities and interest related, off balance sheet contracts is affected by a change in interest rate because the present value of the future cash flow themselves is changed. In financial institutions that manage trading activities separately, exposure of earnings and capital to those activities because of changes in market factors is price risk. This risk arises from market, making dealing and position taking activities for interest rate, foreign exchange equity and commodity markets. Each financial transaction that a bank completes may affect its interest rate risk profile.

2.1.4. Membership enrollment on financial performance of savings and credit cooperatives.

A SACCO member is a person who belongs to that SACCO willingly by filling in the membership form and paying the required membership fees. Most SACCO members have a common bond either of occupational or production nature. This characteristic makes a SACCO to be an association of people who have come together with common goal geared at improving their livelihood economically (Sacco's operations report, 2006). The apex is the Kenya National Federation of Cooperatives which was formed in 1964 to be the spokesman for the cooperative movement, custodian of cooperative principles, control of membership, promote development of the movement and promotes collaborations both locally and internationally, Wanyama(2009). The national cooperative organizations comprise secondary and primary cooperatives that offer specialized services to affiliates such as commercial and financial services and represents union and society at international levels. Under the current law most of the SACCOs in Kenya may close their doors if they do not meet the minimum threshold. For a SACCO to be registered, it must have a minimum of 30 people. The members must also meet the ksh. 10 million capital adequacy requirements. Investment of SACCO funds in non-core business must not be more than $10 \%$ of its total assets. In addition some $15 \%$ of SACCO assets must be in cash form to adequately provide for its liquidity requirements. SACCOs will also be expected to make adequate provision for loan losses as is done by the commercial banks and other financial institutions (SASRA, 2012).

\subsubsection{Duration of loan processing on financial performance of SACCOs}

Several reasons may cause delay in loan processing in a financial institution and this delays may cause impatience to the client because the loan has taken longer period than expected. If you submit your loan application two weeks ago and you have not heard back from your lender you may begin wondering, Blakley(2013). According to Blakley (2013), internal coordination is one of the causes of loan delay. During loan processing the application form passes through the hands of several professionals and for this reason it is easy for the processing to get backlogged. These processes involve the checking of your files by the processing team. Another cause of delay in loan processing is the effect of influx of loan applications. When interest rates are almost to go down the lender may consider locking in some new loan terms. Several financial institutions in the industry have the same thought and hence when the rate drops, the volume of borrowers goes up. This will certainly equate to a longer processing time for your loan. Verification is also another big cause of loan processing delays. Lenders need to fully assess the borrowers risk before choosing to approve or deny a loan request. Among other things this means verifying employment with managers, obtaining credit history from credit bureaus and acquiring rental records from previous landlords. Confirming this information can take long time especially if your references are difficult to contact. The performance of SACCOs depends on their operational efficiency, Nyanjwa(2008) and is greatly hampered by low capacity to operate and manage their activities. It is important to remove all the bottle necks that cause inefficiency hence affecting the overall performance of SACCOs. There is no standardized performance measurement tool to evaluate the status of a SACCO. According to Dan Green (2013) many loan factors are beyond the control of 
borrowers who want to close quickly. For example you cannot control how fast an appraisal is performed because the appraisal requires the cooperation of the seller nor can you control how quickly a title deed search is performed by a title company. Dan Green (2013) in his report, blogs on mortgage, market and other items of interest established that there are steps one can take to make sure that he/she gets loans approved as fast as humanly possible. The first step according to Dan Green (2013) is proper preparation of paper work including application forms and all relevant documents that the lender must require for loan approval. Then do not keep secrets from your lender for the reasons that withholding information can constitute loan fraud, which is far worse outcome than not getting a loan approved.

\subsubsection{Management of loan defaulters and financial performance SACCOS}

Defaulting on payment is a serious offence and should be avoided at all cost. Most of the time defaulting on payments is temporary in nature caused by clients loss of jobs, a temporary extra expenditure that left no money to make the pay or prolonged illness which may cause the client financial distress or keep him in hospital for few months. In very rare cases people default because of permanent failure or sudden death of individual who wasn't insured or did not have enough resources left for his or her family. Temporary causes can be managed through close supervision and monitoring and evaluating the projects financed by the loan. Proper training of loan applicant is necessary before loan disbursement. In developed countries like Germany loan default is not frequent because of the mechanism they use to control and manage loan default. Loan defaults have caused a lot of nonperforming assets (NPAs) in SACCOs and other financial institutions in India. Banks especially those in public sector are in a mess owing to the mounting nonperforming assets. Public sector banks hold $95 \%$ of these defaulting loan accounts. The net nonperforming assets of the 26 public sector banks in India rose to 2.02 percent during the year 2012-2013 from the 1.53 in the previous year. That means loan worth big amounts of money are at the risk of default. Even borrowers who are in a position to pay back the loan are not doing it. This shows a weakness in the governance of the public sector banks in India. The willful defaulters are not treated the same way with the genuine defaulters. There are adequate provisions to deal with willful defaulters although the public sector banks have not been aggressive in implementing (India Weekly Journal, 2014). In his report Yashwant(2014) he was particularly concerned about the mounting non-performing assets in the corporate lending segment as compared to other sectors. A number of finance institutions have been attributed to have managerial failures because of their inability to arrest the rising non-performing assets. A number of business entities have been lining up for restructuring their debt to escape bank action on nonpayment. In restructuring, the terms of the loan are eased up and borrowers get more time to get his house in order.

\subsection{Empirical Literature Review}

MFIs are very important organizations in providing access to financial services especially in poor developing countries where majority of their people cannot access the services of FFIs because they view them as risky borrowers who do not own collaterals. SACCOS are among the MFIs which play important role of mobilizing savings from their members and thereafter issue them to other members who need loans (Miriti, 2014). SACCOS are expected to render better services to their members at relatively lower costs compared to FFIs. In assessing ability of SACCOS in rendering services to their members there are different tools and indicators that are used. Performance is one among the major indicators which are used to measure the extent to which SACCOS are able to render services to their members. Performance of SACCOS depends on their operational efficiency (Nyanjwa, 2008). Other indicators which are used to measure performance of SACCOS include: profitability, asset quality, growth, and return on assets, return on investment, and rate of cost to revenue and many others. Following are some of the most important factors which influence performance of SACCOS: duration or time taken to process loans; amount of defaulters; size of membership; capital adequacy; credit evaluating criteria; and financial liquidity. Time spent in processing loans for members is one of the most important factors which determine performance of SACCOS. If a SACCOS is able to process loans for its members timely and at appropriate rates, then it is considered to be performing well (Microfinance House, 2006). Otherwise, if duration for processing loans is too long, members will be dissatisfied and sometimes withdraw their membership and consequently the SACCOS will underperform and collapse. Rate of loan default is another factor which has direct influence on performance of SACCOS. It affects performance of SACCOS negatively because money which might have been planned to be invested in certain projects in order to generate profits disappears and consequently no interest is obtained. The higher the rate of loan repayment in SACCOS, the higher the chance of collecting revenue in the form of interest and the lower the rate of loan losses in any lending institution (Alfred, 2011). On the other hand, poor loan repayments have a harmful negative impact on SACCOS, earnings, as well as in fulfilling its objectives and can cause the institution to collapse. Huseyin (2011) noted that failure to manage loan repayment results in losses and high delinquency management costs. The higher the expenses of monitoring loan portfolios and costs of handling legal issues associated with serious loans delinquent, the less the rate of performance which will be achieved by the SACCOS. Such costs adversely affect income generated by the lending institutions. Size of membership in SACCOS is another factor that has an influence on financial performance of SACCOS. This implies that SACCOS 
with large number of members has more chances of accumulating large amount of capital and consequently issue more loans compared with the one with small number of members. In addition, large number of membership in SACCOS guarantees flow of revenue and consequently enhances its financial performance.

In a similar study, Makena (2014) found that branding had positive influence on membership of SACCOS through enhanced membership retention, increased in membership and hence shareholders. Capital is another factor which has a direct influence on performance of SACCOS. Capital adequacy is a statutory minimum reserve for capital which a financial institution including SACCOS must maintain and it has a direct influence on performance of the institution. Issuing loans to borrowers who are already overloaded with debts or possess unfavorable loan history can expose SACCOS to unnecessary default and loan risk. In order to decrease these risks, SACCOS and other lending institutions need to take into consideration several common applicants' particulars such as debt to income ratios business and loan history and performance record and for individual loans applicants their time on the job or length of working in their organizations (Mullei, 2013). Liquidity in SACCOS is used to measure the extent to which the organization has cash to meet immediate and short term obligations. Liquidity enables an organization including SACCOS to ensure that it has a reliable supply of cash at hand but also to determine financial health of future investments (Muheebwa, 2018; Clementi, 2001). According to Majid (2003), liquidity is an essential component of the overall risk management framework. He further posits that organizations which have more liquid assets have more chances of performing better as they are able to realise cash at any point in time and meet their obligations and are also less exposed to liquidity risks. There are more factors that have an effect on settling loans which include; inadequate loan follow ups by the management, inadequate collateral verification, bad repayment system and members' failure to honor their obligations (Karumuna and Akyoo, 2011). Representative bodies have urged SACCOs to exercise cautious in admission of new members and have stressed adherence to the savings first principle. Further, representative bodies have urged SACCOs to be alert to the demands of current members. In a climate where access to credit is poor, the access that the members of SACCOs have to credit may be bought by others. Furthermore, with wide spread poverty, a large informal economy and associated informal lending can provide the right climate for exploitative pyramid selling schemes to flourish. In such a context, it was important for SACCOs to adopt and implement mechanisms to verify the validity and authenticity of loan application requests rigorously (Karumuna and Akyoo, 2011). According to a study conducted in Uganda in 2009 showed that the Uganda Cooperatives Transport Union had difficulty in accessing credit. However it seems that this is due to the poor financial state of the cooperative and mismanagement of funds rather than an impact of the financial crisis. For example, it was reported that the union borrowed approximately $\$ 250,000$ USD from Barclays in order to purchase vehicles, however the funds were channeled into operational expenses (Butagira \& Mashoo, 2009).

\subsection{Conceptual framework}

The aim of this study is to identify the major factors affecting financial performances of SACCOS, in Dirash and Alle Woreda; Southern region of Ethiopia. Accordingly, based on the objective of the study, the following conceptual model has been framed. Financial performance of SACCOS are affected by the following factors include loan repayment policy, management of loan defaulter, membership enrollment, interest rate charge and duration of loan processing were analyze as factors affecting non-performing loans.

\section{Fig 1. Conceptual Frame Work Model}

\section{Source; Developed by the researcher 2020}

\section{Research Methodology}

To achieve the objective of the study, the research used descriptive design to identify factors affecting the financial performances of SACCOS; in Derash and Alle Woreda, Southern region of Ethiopia. Descriptive study type of research was used. The strategy adopted in the study contains quantitative methods and tools that are relevant to achieve the desired research outcome. The total populations are 490 SACCOS in Derash and Alle Woreda. To determine sample size Yamane (1967) provides a simplified formula to calculate sample sizes. This formula assumed a $95 \%$ confidence level and margin of error (e) 0.05 . The sample size of the study was determined using the formula: $\mathrm{n}=\frac{N}{1+N(e) 2}$

Where ' $\mathrm{n}$ ' is the sample size, ' $\mathrm{N}$ ' is the population size, and ' $\mathrm{e}$ ' is the level of precision $\mathrm{N}=237$ which is the total population and significant level is $(\mathrm{e})=0.05$. Then, the sample was, $\frac{490}{1+490(0.05) 2}=220$; ample that expecting can represent the total population. 


\begin{tabular}{|c|c|c|c|c|c|c|}
\hline No & $\begin{array}{l}\text { Name of sampled } \\
\text { Woreda }\end{array}$ & ND & $\begin{array}{l}\text { No of } \\
\text { SACCOS }\end{array}$ & $\begin{array}{l}\text { No of } \\
\text { member }\end{array}$ & $\begin{array}{l}\text { Target } \\
\text { population }\end{array}$ & Sample size \\
\hline \multirow[t]{3}{*}{1} & Derashe Woreda & Arguba & 1 & 65 & 65 & $220(65 / 490)=29$ \\
\hline & & Mosiye & 1 & 52 & 52 & $220(52 / 490)=23$ \\
\hline & & Holite & 2 & 84 & 84 & $220(84 / 490)=38$ \\
\hline \multirow[t]{4}{*}{2} & Alle Woreda & Gewada & 2 & 95 & 95 & $220(95 / 490)=43$ \\
\hline & & Wolango & 2 & 105 & 105 & $220(105 / 490)=47$ \\
\hline & & Delibena Gama & 2 & 89 & 89 & $220(89 / 490)=40$ \\
\hline & Total & \multicolumn{2}{|l|}{18} & 490 & 490 & 220 \\
\hline
\end{tabular}

Source: secondary data 2011

\section{DATA ANALYSIS, PRESENTATION AND INTERPRETATION}

\subsection{Demographic characteristics of respondents}

\subsubsection{Distribution of respondents by gender}

Gender was a matter of concern in this study because men and women have different ideologies on matters of savings and investments. The researcher wanted to establish how savings and investment in SACCOs can be influenced by an individual gender status. The findings are presented in table 4.1.

Table 4.1 Respondents by gender

\begin{tabular}{|r|l|r|r|r|r|}
\hline \multicolumn{5}{|c|}{ Gender } \\
\hline \multirow{2}{*}{ Valid } & Male & \multicolumn{1}{|c|}{ Frequency } & Percent & Valid Percent & \multicolumn{1}{c|}{ Cumulative Percent } \\
\cline { 2 - 6 } & Female & 60 & 27.3 & 72.7 & 72.7 \\
\cline { 2 - 6 } & Total & 160 & 72.7 & 27.3 & 100.0 \\
\hline
\end{tabular}

Source from own competition 2020

Out of the 220 respondents who participated in the study $60(27.3 .7 \%)$ were males, $160(72.7 \%)$ were females. All participants responded to this question. This shows that women were more attracted to join SACCOS compared to male.

This is likely to be the case because women in many African societies are the ones who take care of families particularly the old and youth. This family responsibility forces them to join SACCOS in order to get credit which can be used to invest in small businesses which in turn enables them to generate incomes for taking care of their families.

Furthermore, men look for employment outside their families where they can earn more money. This result is consistent with previous study by Chirwa (2004) who found that recently there has been an increase of small businesses owned by women and that they were growing more rapidly compared to male owned businesses. This result is likely to influence financial performance of the SACCOS because studies (Kotur and Anbazhagan, 2014) found that women are more productive than men.

\subsubsection{Distribution of respondents by Age}

The researcher sought to establish the age distribution of respondents so that it can be ascertained how age disparity affects the membership of SACCOs and appointments in SACCO management. The findings of this study are presented in table 4.2 .

Table 4.2 Respondents by age

\begin{tabular}{|l|l|r|r|r|r|}
\hline \multicolumn{2}{|c|}{ Age } \\
\hline \multirow{3}{*}{ Valid } & $20-29$ & Frequency & Percent & Valid Percent & Cumulative Percent \\
\cline { 2 - 6 } & $30-39$ & 20 & 9.09 & 13.6 & 13.6 \\
\cline { 2 - 6 } & $40-49$ & 100 & 45.5 & 45.5 & 59.1 \\
\cline { 2 - 6 } & $50-59$ & 60 & 27.3 & 27.3 & 86.4 \\
\cline { 2 - 6 } & Total & 40 & 18.2 & 13.6 & 100.0 \\
\hline
\end{tabular}

Source from own competition 2020

Table 4.2 shows that out of the 220 respondents who participated in this study, $100(45.5 \%)$ fell in the age bracket of 30-39 years, 60(27.3\%) fell in the age bracket of 40-49 years, 40(18.2\%) were in the age bracket of 5059 years while 20(9.09\%) fell in the age bracket of 20-29 years respectively. At these age groups they may be looking for money for basic family activities like constructing family houses, health services, food and clothes for their families and school fees for their children.

Most members of the SACCOS who were in these ages groups were likely to be strong and energetic and eager to work hard in order to fulfill their psychological demands. This in turn can enable the SACCOS to achieve 
high performance. On the other hand, majority of those who were under the age of 30 years might have just completed tertiary education and hence they may be looking for employment opportunities and hence membership in SACCOS may not be their priorities. In addition, those who were above the age of 60 years might have retired from active services and consequently they may not be interested in joining SACCOS.

\subsubsection{Distribution of respondents by marital status}

The researcher sought to establish the marital status of respondents with the aim of establishing how it affects the saving and investing culture.

Table 4.3 Respondents by marital status

\begin{tabular}{|c|c|c|c|c|c|}
\hline \multicolumn{6}{|c|}{ Martial states } \\
\hline & & Frequency & Percent & Valid Percent & Cumulative Percent \\
\hline \multirow{3}{*}{$\begin{array}{l}\text { Vali } \\
\text { d }\end{array}$} & Married & 190 & 86.4 & 86.4 & 86.4 \\
\hline & single & 30 & 13.6 & 13.6 & 100.0 \\
\hline & Total & 220 & 100.0 & 100.0 & \\
\hline
\end{tabular}

Source from own competition 2020

Table 4.3 shows that $190(86.4 \%)$ were married while $30(13.6 \%)$ were single. Respondents were also asked to indicate their marital status because this factor may have influence on performance of the SACCOS. Results of the question show that $190(86.4 \%)$ of the respondents were married $30(13.6 \%)$ were single. From this result it shows that majority of the respondents $(86.4 \%)$ were married couples with family responsibilities and this might be one of the reasons which prompted them to join the SACCOS in order to access credit which can be invested in projects for the purpose of generating incomes for their families. This is likely to motivate them to participate actively in the affairs of the SACCOS in order to get income and good services. This implies that married members of SACCOs have more financial demands as compared to single because they need to educate their children, establish their families and develop house hold assets.

4.1.4 Distribution of respondents by nature of duty

The researcher sought to establish the nature of duty either staff, member or management. This was supposed to enable the researcher to get varied responses from the different categories.

Table 4.4 Respondents by nature of duty

\begin{tabular}{|l|l|r|r|r|r|}
\hline \multicolumn{7}{|c|}{ Nature of duty } \\
\hline \multirow{2}{*}{$\begin{array}{l}\text { Vali } \\
\text { d }\end{array}$} & Management & Frequency & Percent & Valid Percent & Cumulative Percent \\
\cline { 2 - 6 } & Staff member & 10 & 4.5 & 4.5 & 4.5 \\
\cline { 2 - 6 } & Total & 210 & 95.5 & 95.5 & 100.0 \\
\hline
\end{tabular}

Source from own competition 2020

Table 4.4 shows that $210(95.5 \%)$ are staff members and $10(4.5 \%)$ are management. This shows that the majority of the respondents are the staff members in SACCOs and the remaining are managements of SACCOs who managing the overall activity and putting strategic plan.

4.1.5 Distribution of respondents by Association

The researcher was trying to assess the period undertaken by the respondent in a SACCOS. A Long association of members is important as they know the trend of members' loan repayment, loan defaulters and how good the members' enrolment in the SACCOS is.

Table 4.5 Association of Responder

\begin{tabular}{|c|c|c|c|c|c|}
\hline \multicolumn{6}{|c|}{ How long have you been associated with the SACCOS? } \\
\hline & & Frequency & Percent & Valid Percent & Cumulative Percent \\
\hline \multirow{3}{*}{$\begin{array}{l}\text { Vali } \\
\text { d }\end{array}$} & $1-3$ years & 130 & 59.1 & 59.1 & 59.1 \\
\hline & $4-6$ years & 90 & 40.9 & 40.9 & 100.0 \\
\hline & Total & 220 & 100.0 & 100.0 & \\
\hline
\end{tabular}

Source from own competition 2020

Table 4.5 shows that those who associated below one year were 130 respondents which was equivalent to 59.1 percent, those who are in between 1 to 3 years were 90 respondents equivalent to 40.9 percent, those who are between 4 to 6 years. In fact, those associated less than one year and those of above 6 years fall at the same level.

\subsection{Descriptive Analysis for Factors Affecting Financial Performances of SACCOS \\ 4.2.1. Loan Repayment Policy}

The survey result indicated the degree of agreement or disagreement to the statements affecting loan repayment policy for the occurrences of financial performance of SACCOs. 
Table 4.6 Factors Indicating loan repayment policy

\begin{tabular}{|c|c|c|c|c|}
\hline \multicolumn{5}{|c|}{ Descriptive Statistics } \\
\hline & Disagreement & Agreement & Mean & Std. D \\
\hline $\begin{array}{l}\text { There is maximum loan repayment period is Five } \\
\text { year }\end{array}$ & $36.4 \%$ & $63.6 \%$ & 3.05 & 1.150 \\
\hline $\begin{array}{l}\text { There is a repayment terms and condition are open } \\
\text { to members }\end{array}$ & $36.4 \%$ & $63.6 \%$ & 3.59 & .889 \\
\hline Lack of properly Loan monitoring and evaluation & $31.8 \%$ & $68.20 \%$ & 3.50 & 1.343 \\
\hline $\begin{array}{l}\text { Monthly cash installment system are not properly } \\
\text { apply for members to repay their loan }\end{array}$ & $45.5 \%$ & $54.5 \%$ & 3.32 & 1.398 \\
\hline $\begin{array}{l}\text { Amount of loan issued to members have not full } \\
\text { security }\end{array}$ & 0 & $100 \%$ & 4.86 & .344 \\
\hline
\end{tabular}

Source from own competition 2020

In the above Table 4.6, the results shows; there is maximum loan repayment period is Five year, about $63.6 \%$ are agreed and $36.4 \%$ of respondents disagreed that management sets a maximum repayment period of five years. Standard repayment periods are the best option. The loan is paid off fastest with a slightest amount of interest, while a longer repayment period will reduce the monthly payment, but greatly increases how much interest one will be required to repay. Extended repayment plans allow for paying less now and more lately. These plans cost more, due to more interest accrued over time. Of course, the longer the repayment periods are drawn out, the more interest is paid, and the greater the cost to the loan beneficiary.

On the other hand there is a repayment terms and condition are open to members, $63.6 \%$ of respondents are indicated agreement and the rest $36.4 \%$ of the interviewers were disagreed with the mean value of 3.59 and std. deviation 0.889 were forwarded their opinion. The finding reviled that there is a repayment terms and condition are open to members this means loan repayment terms and condition meaning that only the assessed eligible members required getting loan equal or lower than the amount requested by the borrower. The current findings are supported by Absanto and Aikaurwa (2013) of which in their findings they revealed that the amount of loan applied and disbursed to members was less than loan applications received implying that SACCOS applies some criteria to ration loans applied by members. What is observed is that credit rationing where all applicants could not be eligible for the loan and even those who are eligible get less amount than the amount requested.

For the item Lack of properly Loan monitoring and evaluation, $68.2 \%$ of the respondents are voted agreement and the rest $31.8 \%$ of the respondents are disagreed with the mean value of 3.50 with the value of std. deviation 1.343 were forwarded their opinion. The finding reviled that the lack of properly loan monitoring and evaluation are the major factor for loan repayment police. This confirms that poorly loan monitoring and evaluation are leads to loan default and it minimizing the financial performance of SACCOs. But if properly monitored poorly assessed loans it must be well performed loans or minimize the occurrences of loans default.

For the item Monthly cash installment systems are not properly applied, $54.5 \%$ of the respondents are voted agreement and the rest $45.5 \%$ of the respondents are disagreed with the mean value of 3.32 with the value of std. deviation 1.398 were forwarded their opinion. The finding reviled that the monthly cash installment systems are not properly applied this is also the major factor for loan repayment police. This confirms that for members to repay their loan are face problem while using the repayment system. Meaning there might be fault in the system or not familiarized with the system.

The survey results indicated in the above table, Amount of loan issued to members have not full security, $100 \%$ of the respondents are voted agreement with the mean value of 4.86 with the value of std. deviation 0.344 were forwarded their opinion. The finding reviled that the amount of loan issued to members have not full security this indicted factor for loan repayment policy. Meaning with reference to lending, security or collateral, is an asset that is pledged by the borrower as protection in case he or she defaults on the repayment. Under the loan agreement, the lender could have the right to take ownership of the asset in place of the repayment, or he or she might have the right to insist that the asset is sold to repay the outstanding loan and, with the remainder of the proceeds returned to the borrower. Security should be important to the lender, whether the borrower is an individual or a member of SACCOs.

\subsubsection{Management of loan defaulters}

The survey result indicated the degree of agreement or disagreement to the statements affecting managements of loan defaulters for the occurrences of financial performance of SACCOs. 
Table 4.7 Factors Indicating Management of loan defaulters Descriptive Statistics

\begin{tabular}{|l|r|r|r|r|}
\hline & Disagreement & Agreement & \multicolumn{1}{c|}{ Mean } & Std. D \\
\hline $\begin{array}{l}\text { The SACCOS does not limits in loan amount to } \\
\text { collateral value }\end{array}$ & $36.4 \%$ & $63.6 \%$ & 3.59 & .889 \\
\hline The borrowers inability to pay loan & $31.8 \%$ & $68.2 \%$ & 3.50 & 1.343 \\
\hline $\begin{array}{l}\text { There is inefficient credit procedures are cases } \\
\text { loan defaulters }\end{array}$ & $40.9 \%$ & $59.10 \%$ & 3.23 & 1.206 \\
\hline $\begin{array}{l}\text { Legal action does not properly taken to loan } \\
\text { defaulter }\end{array}$ & $77.3 \%$ & $22.7 \%$ & 3.27 & 1.138 \\
\hline $\begin{array}{l}\text { Lack of adequate knowledge to borrowers in credit } \\
\text { processing }\end{array}$ & $13.63 \%$ & $86.37 \%$ & 3.95 & .769 \\
\hline
\end{tabular}

Source from own competition 2020

The survey results indicated in the above table 4.7, SACCOs does not limits in loan amount to collateral value, $63.6 \%$ of the respondents are voted agreement and the rest $36.4 \%$ of the respondent are disagreed with the mean value of 3.59 and with the value of std. deviation 0.889 were forwarded their opinion. The finding reviled that SACCOS does not limits in loan amount to collateral value this indicted factor for management of loan defaulter.

Meaning Secured lenders will often lend a maximum total amount of approximately $70 \%$ of a secured asset's collateral value. Mortgage loans generally follow standard underwriting procedures with these variables also a part of the decision on how much to lend to a borrower. A maximum loan amount for a borrower is based on a combination of factors and determined by a loan guarantor. Lenders consider a borrower's debt to income ratio during the underwriting process, which helps to determine how much they believe the borrower would be able to repay and therefore what the maximum loan amount should be. Lenders generally seek borrowers with debt-toincome ratios of $36 \%$ or less. Lenders must also consider their own risk parameters when determining a borrower's total principal. Thus, maximum loan amounts can also be based on the risk diversification of a lender.

The survey results indicated in the above table 4.7 , the borrowers cannot be ability to pay loan, $68.2 \%$ of the respondents are voted agreement and the rest $36.4 \%$ of the respondent are disagreed with the mean value of 3.59 and with the value of std. deviation 0.889 were forwarded their opinion. The finding reviled that the borrowers unable to pay the loan this indicated factor for management of loan defaulter. This implies that inability of loan repayment is due to intentional (willful) default, unwillingness of borrower to pay back the loan, lack of sufficient supervision from the SACCOs.

When a borrower fails to repay the loan inability to repay a loan for an extended period leads to the deterioration of the relationship between the borrower and the lender. In this situation the SACCOs needs active management

The survey results indicated in the above table, there is inefficient credit procedures are cases loan defaulters, Lack of adequate knowledge to borrowers in credit processing, $59.10 \%$ and $89.37 \%$ of the respondents are voted agreement and the rest $40.9 \%$ and $13.63 \%$ of the respondent are disagreed with the mean value of 3.23 and 3.95 with the value of std. deviation 1.206 and 0.769 respectively were forwarded their opinion. The finding reviled that there is inefficient credit procedures, lack of adequate knowledge to borrowers are factors for management of loan defaulter.

\subsubsection{Membership enrollment}

The research aimed to analyze how membership enrollment helps the Cooperative Societies become financially sustainable.

Table 4.8 Factors Indicating membership enrollment

\begin{tabular}{|l|r|r|r|r|}
\hline Descriptive Statistics & \multicolumn{1}{|c|}{ Disagreement } & Agreement & \multicolumn{1}{c|}{ Mean } & Std. D \\
\hline Items & $9 \%$ & $91 \%$ & 4.68 & .764 \\
\hline Dividend has been declaring for the last two years & $40.9 \%$ & $59.1 \%$ & 3.23 & 1.128 \\
\hline $\begin{array}{l}\text { There is high Interest on savings are determines } \\
\text { membership enrollment }\end{array}$ & $45.9 \%$ & $54.1 \%$ & 3.36 & 1.112 \\
\hline $\begin{array}{l}\text { There is high rate of savings are affect Membership } \\
\text { enrollment }\end{array}$ & $13.63 \%$ & $86.37 \%$ & 4.23 & .999 \\
\hline $\begin{array}{l}\text { External borrowing is a factor for membership } \\
\text { enrollment }\end{array}$ & & & \\
\hline
\end{tabular}

Source from own competition 2020

The survey results indicated in the above table 4.8, Dividend has been declaring for the last two years, $91 \%$ of the respondents are agreed and the rest $9 \%$ of the respondents disagreed with the mean value of 4.64 and the standard division of 0.764 . The result revealed that, dividend has been declaring for the last two years which helps 
SACCOS to sustain is the provision of dividend to members each year, this results to an increase of a number of members because they will expect receiving a return on their investment, hence this leads to sustainability of SACCOS

The survey results indicates that, there is high Interest on savings are determines membership enrollment, with $59.1 \%$ of the respondents are agreed and the rest $40.9 \%$ of the respondents disagreed with the mean value of 3.23 and the standard division of 1.128. The result revealed that, most respondent agreed with the factor that, there is high interest on savings results to a capital growth. This is due to high membership enrollment as a result of interest provided by SACCOS on members' savings.

The survey results indicates that, there is high rate of savings are affect Membership enrollment, with $54.1 \%$ of the respondents are agreed and the rest $45.9 \%$ of the respondents disagreed with the mean value of 3.36 and the standard division of 1.112. The result revealed that, most respondent agreed with the factor that, there is high rate of savings results to a SACCO sustain. The more members are enrolled to the SACCOS the higher the amount of savings, hence the better capital growth will be.

The survey result indicates, $86.37 \%$ of respondents are agreed and the rest $13.63 \%$ of the respondents are disagreed with the mean of 4.23 and a standard deviation of 0.999 . The result revealed that, most respondent agreed with the factor that, there is external borrowing is a factor for membership enrollment this observed by members regarding the influence of external borrowing from other financial institutions helps to pool members into the SACCOS.

\subsubsection{Interest rate charged}

The survey result indicated the degree of agreement or disagreement to the statements affecting interest rate charged for the occurrences of financial performance of SACCOs.

Table 4.9 Factors Indicating interest rate charged

\begin{tabular}{|c|c|c|c|c|}
\hline \multicolumn{5}{|l|}{ Descriptive Statistics } \\
\hline & Disagreement & Agreement & Mean & Std. D \\
\hline There is high level of interest charged by SACCOS & $13.63 \%$ & $86.37 \%$ & 4.05 & .769 \\
\hline There is high level of interest charge on saving & $45.9 \%$ & $54.1 \%$ & 3.41 & 1.075 \\
\hline The level of inflation rate for the last two years are very high & $36.3 \%$ & $63.7 \%$ & 3.05 & 1.109 \\
\hline
\end{tabular}

Source from own competition 2020

Based on the above table 4.9 the respondent were give their opinion concerning there is high level of interest charged by SACCOS, $86.37 \%$ of respondents are agreed and the rest $13.63 \%$ of the respondent are disagreed with the mean value of 4.05 and Standard devotion of 0.769 . The finding reveled that there is high level of interests which were being charged by the SACCOS in the study area. This is because rates of interests charged by any financial institution have a direct influence on performance of the institution. When rate of interest being charged is high, most depositors are likely to withdraw from the institution but when rate of interest being charged is low more depositors will be attracted to join the institution.

The finding also supported by Toli (2013) getting loan is the primary benefit that members expect after joining SACCOs. Interest on loan is the source of income for SACCOs. Income for SACCOs is expense for members. This indicates that as the level of interest rate on borrowing increases it decreases the loan size and peoples did not initiated to borrow money and this declines the performances of SACCOS. This supports the findings of Campion, A., Ekka, R. K., \& Wenner, M. (2010) that excessively high interest rates can attract negative publicity. Also Cull.R, Kunt.A.D and Morduch.J (2006) mentioned that there is a negative association between charging higher interest rates and having a large customer base. Hulme D. and Mosley P. (1996) also mentioned that saving schemes, intensive loan collection and market interest rate has higher loan impact at a given level of average borrower poverty.

The survey results indicates that, there is high level of interest charge on saving, with $54.1 \%$ of the respondents are agreed and the rest $45.9 \%$ of the respondents disagreed with the mean value of 3.41 and the standard division of 1.075. The finding reviled that, there is high level of interest charge on saving this indicates that if SACCOS pay high interest rate they can attract many members and also at the same time they can increase their loan size. SACCOs pay interest on members' deposit. Setting compatible interest rate may attract members especially to save additional amount above forced saving. This is further supported by Mwakajumilo (2011) who stated that SACCOs can attract savings and encourage members to draw away their account from banks by offering competitive interest rates. Relampagos, Lamberte and Graham (1990) also stated that members saving behavior can be determined by the interest rate on fixed deposit.

The survey results indicates that, the level of inflation rate for the last two years are very high, with $63.7 \%$ of the respondents are agreed and the rest $36.3 \%$ of the respondents disagreed with the mean value of 3.05 and the standard division of 1.109. The finding reviled that the level of inflation in the country for the past 2 years as being high. This show the reason why some SACCO members said the interest rate charged is high. Inflation is a factor beyond the control of the SACCO therefore the SACCO should look for other ways of controlling its lending rate like trying to minimize other operations cost. 


\subsubsection{Duration of loan processing}

The survey result indicated the degree of agreement or disagreement to the statements affecting duration of loan processing for the occurrences of financial performance of SACCOs.

Table 4.10 Factors Indicating duration of loan processing

\begin{tabular}{|c|c|c|c|c|}
\hline \multicolumn{5}{|l|}{ Descriptive Statistics } \\
\hline & Disagreement & Agreement & Mean & Std. D \\
\hline $\begin{array}{l}\text { Lack of adequate knowledge and attitude towards loan } \\
\text { processing }\end{array}$ & $36.3 \%$ & $63.7 \%$ & 3.59 & 1.233 \\
\hline There is poor loan processing and approval techniques & $31.8 \%$ & $68.2 \%$ & 2.59 & 1.374 \\
\hline There is a Number of days taken to process loans & $27.2 \%$ & $72.8 \%$ & 2.18 & 1.406 \\
\hline Lack of appropriate funds to rise the loan to borrowers & $31.4 \%$ & $68.6 \%$ & 3.05 & 1.150 \\
\hline There is problem in selecting applicant criteria & $36.3 \%$ & $63.7 \%$ & 3.59 & .889 \\
\hline
\end{tabular}

Source from own competition 2020

The above table 4.10 indicted that lack of adequate knowledge and attitude towards loan processing, there is poor loan processing and approval techniques, there is a Number of days taken to process loans, Lack of appropriate funds to rise the loan to borrowers and there is problem in selecting applicant criteria with mean 3.59, $2.59,2.18,3.05,3.59$ and the value of standard devotion of $1.233,1.374,1.406,1.150$ and 0.889 respectively. The finding revel that factor for duration of loan processing in SACCOS are due to lack of adequate knowledge and attitude towards loan processing, there is poor loan processing and approval techniques, there is a number of days taken to process loans, Lack of appropriate funds to rise the loan to borrowers and there is problem in selecting applicant criteria. This implies that SACCO delayed loan processing cases for loss of revenue to the SACCO in form of interests and hence affect the eventual performance thus we can say that duration of loan repayments affects the performance of SACCO. We see a relationship between members shift to other institution with increase in complaints about delayed in loan processing. Thus we conclude that delay in loan repayment will affect the performance of SACCO.

\section{Conclusions}

* Among the factors that have links with SACCOs Financial Performance, The finding revel that factor for duration of loan processing in SACCOS are due to lack of adequate knowledge and attitude towards loan processing, there is poor loan processing and approval techniques, there is a number of days taken to process loans, Lack of appropriate funds to rise the loan to borrowers and there is problem in selecting applicant criteria. This finding was supported with Miriti (2014) in his finding he noted that, when Capital SACCO member's source loan from other commercial banks due to delayed of loan processing in their SACCO it translated to loss of revenue to the SACCO in form of interests and hence affects the eventual performance.

* The next predicting factor that was also more important was the loan repayment policy. In related with loan repayment policy the survey result depicts that poor loan repayment policy are the significant relationship with financial performances of SACCOs with regard to inefficient loan monitoring and cash installment system. This implies that the SACCOs has been poorly assessing and evaluating loan monitoring, inadequate cash installment system and loan issued to members have not full security due to inadequate collateral value assessment of the respective customer or members and the risk associated with the loan. This finding was supported with Besley (2003) he found that administrations of loan repayment are the major problem in developing countries. Most lending institutions do not have experienced personal capable of developing appraisal procedures for different category of borrowers. The poor loans repayment is recognized as one of the most troublesome problem facing rural SACCOs in Africa. Collateral, access to basic information and appropriate loan mechanism to enforce loan repayment are important tools.

* The output related with management of loan defaulter the survey result shows that poor management of loan defaulter are the significant relationship with financial performances of SACCOs. This implies that the SACCOs has been used poor credit procedure, inadequate loan amount to collateral value, unwillingness of borrower to pay back a loan, lack of properly taking legal action to loan defaulter, lack of awareness of borrower in credit processing.

* On the other hand interest rate charge the survey result shows that there is high level of interest charged by SACCOS, this indicted that there is high level of interests is being charged by the SACCOS in the study area. This is because rates of interests charged by any financial institution have a direct influence on performance of the institution. When rate of interest being charged is high, most depositors are likely to withdraw from the institution but when rate of interest being charged is low more depositors will be attracted to join the institution. The survey results indicates that, there is high level of interest charge on saving, this reviled that, there is high level of interest charge on saving this indicates that if SACCOS pay high interest rate they can attract many members and also at the same time they can increase their loan size. On the other hand the survey results indicates that, the level of inflation rate for the last two years are very high, this shows that the level of 
inflation in the country for the past 2 years as being high. The finding also supported by Toli (2013) he found that interest on loan is the source of income for SACCOs. Income for SACCOs is expense for members. This indicates that as the level of interest rate on borrowing increases it decreases the loan size and peoples did not initiated to borrow money and this declines the performances of SACCOS. According to Campion, A., Ekka, R. K., \& Wenner, M. (2010) those mentioned that excessively high interest rate there is a negative association between charging higher interest rates and having a large customer base, saving schemes, intensive loan collection and market interest rate has higher loan impact at a given level of average borrower poverty.

* Finally, regarding on membership enrollment the survey result shows that Dividend has been declaring for the last two years, this revealed that, dividend has been declaring for the last two years which helps SACCOS to sustain is the provision of dividend to members each year, this results to an increase of a number of members because they will expect receiving a return on their investment, hence this leads to financial performances of SACCOS. On the other hand the survey result indicates that, there is high Interest on savings is determines membership enrollment; with $59.1 \%$ most respondent agreed with the factor that, there is high interest on savings results to a financial performance. This is due to high membership enrollment as a result of interest provided by SACCOS on members' savings. Finally, the survey results indicates that, there is high rate of savings are affect Membership enrollment; with 54.1\% most respondent agreed with the factor that, there is high rate of savings results to a SACCO performance. The more members are enrolled to the SACCOS the higher the amount of savings, hence the better financial performance will be.

\section{Recommendation}

It is apparent that SACCOs need to seriously consider all the internal and external factors causing financial performance. Based on the analysis of research findings the following recommendations are advocated for further research:

* This study should recommended that SACCOs are advised to emphasize on the problems of loan repayment policy, loan processing and managing loan default by clearly and effectively communicating with lending staff regarding loan policy, procedures and objectives and ensure to discount future occurrences of credit risk or losses. Indeed, in order to pursue the objective of preventing loans default to damage the efficiency and profitability of the SACCOs, appropriate authorities are advised to get engaged in implementing some mechanisms such as timely follow-up with the credit customers, and consistently advising them over the credit collection policies.

* The SACCOs should assessing the problem related with delayed in loan processing by providing adequate knowledge and attitude towards loan processing and approval techniques

* The SACCOs should minimize a number of days taken to process loans, allocate appropriate funds to raise the loan to borrowers and use effective applicant selecting criteria.

* The SACCOs should evaluating Loan repayment policy by properly monitored poorly assessed loans it must be well performed loans or minimize the occurrences of loans default.

* The SACCOs should prepare awareness creation to borrowers regarding credit service of the SAACOs to improve willingness of borrower to pay back a loan. The management should improve adequate collateral value to loan amount and appropriate legal action to be taken during loan default.

* In general to increasing the financial performance it suggests that SACCOs in the region should strengthen its applicant screening criteria and due diligence assessment to select potential risk taking applicants and adopt appropriate pre and post credit risk assessments. Besides, the SACCOs needs to make sure that borrowed funds are being used for the intended purpose through enhanced credit monitoring.

\section{REFERENCES}

1. Absanto, G. and Aikaurwa, D. (2013). Credit Rationing and Loan Repayment Performance: A case study of Victoria SACCOS. Global Advanced Research Journal of Management and Business Studies, 2(6), 328-341. Retrieved on 5th March, 2016 from garj.org/.../credit rationing-and-loan-repayment performance-the-case-study.

2. Amina, A. (2016). The Effect of Core Capital on the Financial Performance of Deposit Taking SACCOS in Nairobi County D63/68917/2013. Birchall, J. (2004). Cooperatives and the Millennium Development Goals. Geneva: ILO.

3. Burgess, R. G. (1984). In the Field: An Introduction to Field Research. London: Unwin Hyman.

4. Bwana, K. M. and Mwakujonga, J. (2013). Issues in SACCOS Development in Kenya and Tanzania: The Historical and Development Perspectives. Developing Country Studies, 3(5), 114-121. Cobia, D. (1989). Co-operatives in agriculture. Englewood Cliffs, New Jersey: Prentice-Hall, Inc.

5. Creswell, J. (2002). Educational research: Planning, conducting, and evaluating quantitative and qualitative research. Upper Saddle River, NJ: Merrill Prentice Hall.

6. Creswell, J. (2003). Research design: Qualitative, quantitative and mixed methods approaches (2nd ed.). 
Thousand Oaks, CA: SAGE Publications.

7. David, G. K. (2016). Impact of Prudential Regulation on Financial Performance of Deposit Taking Savings and Credit Co-operative Societies in Kenya. Retrieved on 7th June, 2016 from http://ir.jkuat.ac.ke/.../.

8. Drucker, P. F. (1974). Management: Tasks, Responsibilities and Practices. New York: Harper \& Row. Economic Report on Africa (2015), Urbanization and Industrialization for Africa's Transformation. Publications Economic Commission for Africa Fisher, R. J. (2005). Poverty and Conservation Landscapes, People and Power. Series No.2. Sydney: IUCN.

9. Friedman, M. (1957). A Theory of the Consumption Function. Princeton: Princeton University Press.

10. George, D. and Mallery, P. (2003). Reliability analysis. SPSS for Windows, step by step: a simple guide and reference, (14th edn). Boston: Allyn \& Bacon.

11. Gladys, M. M. (2012). Relationship between Financial Structure and Growth of Saving and Credit Cooperative Societies' Wealth in Machakos County. Unpublished Master's project degree, University of Nairobi, Kenya. Retrieved on 11th May, 2017 from erepository.uonbi.ac.ke/.../.

12. Gliem, J. A. and Gliem, R. R. (2003). Calculating, Interpreting and Reporting Cronbach's Alpha Reliability Coefficient for Likert - Type Scale. Midwest Research for Practice Conference in Adult, Continuing, and Community Education. Retrieved on 23rd March, 2016 from https://scholarworks.iupui.edu/handle/1805/344.

13. Grayson, D. (2004). Some myths and legends in quantitative psychology. Understanding statistics,3(2),101-134. Retrieved on 11th June, 2017 from,

14. Guérin, I., Kumar, S. and Agier, I. (2013). Women's empowerment: Power to act or power over other women? Lessons from Indian microfinance. Oxford Development Studies, 41(1), 76-94. Retrieved on 22nd July, 2017 from http://www.documentation.ird.fr/hor/fdi:010060476.

15. Hall, R. E. (1978). Stochastic Implications of the Life Cycle-Permanent Income Hypothesis: Theory and Evidence. Journal of Political Economy, 86, 971- 987. Retrieved from www.journals.uchicago.edu/doi/abs/10.1086/260724 on 16th May, 2016.

16. Jesse, M. K. (2016). Stakeholders Management Strategies and Financial Performance of Deposit Taking SACCOS. Unpublished PhD thesis, Jomo Kenyatta. University of Agriculture, Kenya. Retrieved on 18th September, 2016 from ir.jkuat.ac.ke

17. Joseph, M. K. (2014). Factors Influencing the Performance of Selected "Matatu" SACCO Societies Operating in Kitui County. Unpbulished MBA project, University of Nairobi, Kenya. Retrieved on 25th November, 2016

18. Karagu, J. M. and Okibo, B. (2014). Financial Factors Influencing Performance of Savings and Credit Cooperative Organization in Kenya. International Journal of Academic Research in Accounting, Finance and Management Sciences, 4(2), 295-306.

19. Kasungwa, E. M., and Moronge, M. (2015). Drivers of Sustainability of Agricultural Cooperatives in Kenya: A case of Machakos County. Journal of Management, 3(2), 271-295. Retrieved from www.strategicjournals.com on 19th August, 2016.

20. Kato, M. P., and Kratzer, J. (2013). Empowering women through microfinance: Evidence from Tanzania. ACRN Journal of Entrepreneurship Perspectives, 2(1), 31-59. Retrieved from journals.acrn.eu/resources/Journals/201302c.pdf on 5th May, 2020.

21. Kevin, O. (2016). Growth Strategies and Transformational Orientation Adopted by Unatas SACCOS in Kenya. Unpublished MBA research project, University of Nairobi, Kenya. Retrieved on 4th April, 2016.

22. Kothari, C. R. (1990). Research Methodology-Methods and Techniques, New Delhi: Wiley Eastern Limited. Leach, F., and Sitaram, S. (2002). Microfinance and women's empowerment: A lesson from India. Development in Practice, 12(5), 575-588.

23. Leedy, P. and Ormrod, J. (2001). Practical research: Planning and design (7th ed.). Upper Saddle River: SAGE Publications.

24. Magali, J. J. (2014). Variables for Modeling SACCOS in Tanzania. Asian Journal of Finance and Accounting, 6(1), 198-209.

25. Magali, J. J. (2013). Are Rural SACCOS in Tanzania Sustainability. International Journal of Management Sciences and Business Research, 3(1), 2226-8238. Retrieved on 1st May, 2020 from www.academia.edu/27904618/.

26. Marwa, N. W. (2015). Efficiency and Sustainability of Savings and Credit Cooperatives. ERSA working paper 529. Retrieved on 3rd March, 2017 from https://econrsa.org/system/files/publications/working.../.pdf.

27. Miriti, J. M. (2014). Factors Influencing Financial Performance of Saving and Credit Cooperative Societies. A case of Meru County Kenya. Unpublished MBA research project, University of Nairobi, Kenya. Retrieved from erepository.uonbi.ac.ke/handle/11295/74255 on 15th May, 2016. 
28. Mumanyi, E. A. L. (2014). Challenges and opportunities facing SACCOs in a devolved system of government in Kenya. International Journal of Social Sciences and Entrepreneurship, 1(9), 1-24. Retrieved on 6th Apr, 2020 from https://www.ijsse.org/articles/ijsse_v1_i9_288_314.pdf.

29. Nibissa, N. (2015). Determinant of Savings and Credit Cooperative Society in Addis Ababa. Unpublished MBA thesis, Addis Ababa University, Ethiopia. Retrieved on 19th may, 2020 from http://etd.aau.edu.et/bitstream/123456789/7839/1/Nigusie\%20Dibissa.pdf.

30. Nkuru, F. N. (2015). Factors affecting Growth of SACCOS within the Agricultural Sector in Kenya: A Case of Meru Farmers SACCOS. Global Journal of Commerce and Management Perspective, 4(1), 3445. Retrieved on $19^{\text {th }}$ September, 2016 from http://gifre.org/library/upload/volume/34-45- FACTORSvol-4-1-gjcmp.pdf.

31. Olando, C. O. (2012). An Assessment of Financial Practice as a Determinant of Growth of Savings and Credit Cooperative Societies Wealth. Unpublished $\mathrm{PhD}$ thesis, Kenyatta , Kenya.

32. Olando, C. O., Jagongo A., and Mbewa M. O. (2013). The Contribution of SACCO Financial Stewardship to Growth of SACCOS in Kenya. International Journal of Humanities and Social Science, 3(17), 112132.

33. Patrick, L., Obeid, G., and Njau, J. (2014). Corporate Governance Practices and Performance of Cooperative Financial Institution. The International Journal of Business and Management, 2(10), 67-75. Retrieved on 1st May, 2020 from www.theijbm.com/force_download.php?file_path=wpcontent/uploads/2014/.

34. Popper, K. (1959). The Logic of Scientific Discovery. London: Routledge Classics. Reichel, M., and Ramey, M. A. (1987). Conceptual frameworks for bibliographic education: Theory into practice. Littleton, Colo: Libraries Unlimited.

35. Saunders, M. N. K., Lewis, P. and Thornhill, A. (2009). Research methods for business students. 5th edition.

36. Harlow: FT Prentice Hall. URT, (2007). National Strategy for Growth and Reduction of Poverty (NSGRP), Dar es Salaam: Goverment Printer.

37. Wanjala, S. N. (2015). Effect of Cash Management Practices on the Growth of Matatu SACCOS in Kimilili Sub-county Bungome couny, Kenya. The International Journal of Business and Management, 2(9), 30-41. Retrieved on 1st May, 2017 from www.theijbm.com/force download.php?

38. Waweru, K. M. (2011). An investigation into the cash balance management challenges in Saving and Credit Co-operative Societies (SACCOs) in Nakuru County, Kenya. Journal of Research in International Business and Management, 1(5), 119-123. Retrieved from www.interesjournals.org/.../aninvestigationinto-the-cash-balance-management-challe on $26^{\text {th }}$ June, 2017.

39. Weihrich, H., and Koontz, H. (1993). Management: A Global Perspective. Kuala Lumpur: McGraw-Hill. Yamane, T. (1967). Statistics: An Introductory Analysis, (2nd ed.). New York: Harper \& Row. 